\title{
Kșemendra の伝記的記述について
}

\section{岩 井昌 悟}

\section{O. 問題の所在}

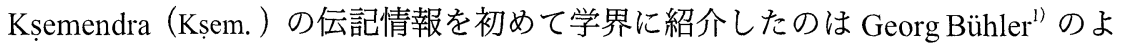
うである。しかし，Sūryakānta [1954］ ${ }^{2)}$ の公刊以来，これが Kșem. の伝記に関 して最も基本的な参考文献になり，その後の多くの研究者， N. S. Shukla ${ }^{3)}$, Uma Chakraborty), A. K. Warder ${ }^{5)}$ 等にほぼ無批判に用いられている.

Kșem. の伝記情報の源は, Rāmāyanamañjar $\bar{l}^{-6)} \cdot(R M)$, Bhäratamañjarī $(B h M), B$ rhatkathāmañjarī (BKM), Samayamātrkā $(S M)$, Aucityavicāracarcā $(A V C)$, Daśāvataracarita $(D C)$ の末尾にある奥書のような数偈と, Kșem. の息子 Somendra (Som.) が Avadānakalpalatā (AK) に付した後書 ”) とが，その主たるものである。そこに は, Kșem. の家系, 父親 Prakāśendra の人となり, 師匠, 彼に作品の執筆を依頼 した人物の名, 協力者, 著作の成立年とその時の王の名等が記されている.

Sūryakānta の研究が発表された当時と現在とで, 参照できる資料にそれほど違 いはないのであるから，彼が紹介した Ksem. の伝記情報につけ加えることはあり そうもない.しかし, 検証は必要であろうと考え, 筆者がその情報源に直接あたつ て見た結果，訂正すべき点と付け加えるべき点が出てきた。

\section{1. $B K M$ の A. D. 1037 年成立説について}

今の所, 誰が最初にこの説を提示したのか不明であるが,一般に $B K M$ の成立は A. D. 1037 年とされている。 その根拠として挙げられる偈文は次のものである. kadācid eva vipreṇa sa dvādaśyām upoṣitạ | prārthito rāmayaśasā sarasạ̣ svacchacetasāa $\| B K M \quad$ (p. 620, 39)

誰もこの偈を訳出していないので推測になるが, 下線部の ‘dvādaśī’を「第 12 年」と読み, ここに, Rāmayaśas が Kșem. にBKM 執筆を依頼した年代（Laukika era 4112 年=A. D. 1037 年）が記されていると見なされたようである. 
Kṣem.は， $B K M$ 以下の著作では， $S M$ の成立を「第 25 年 Paușa 月の初日（saṃvatsare pañcaviṃśe pauṣaśuklādivāse) 」, $A V C$ の成立を「第 34 年の Jyeșța 月の白分の 8 日 (saṃvatsare catustrimśs jyeșthe śukle 'ștame ’hani)」 ${ }^{5)}, D C$ の成立を「第 41 年の Kārttika 月 (ekādhike 'bde... catvāriṃse... kārttike)」とし, Som. は $A K$ の成立を「第 27 年の Vaiśākha 月の白分 (saṇvatsare saptaviṇśe vaiśākhasya sitodaye)」として, 下二桁

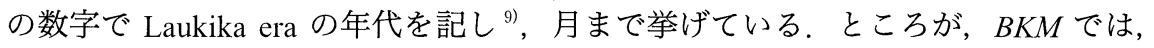
'saṇvatsara’や ‘abda'という「年」という語がなく, 月名も記されていない。し かも, ‘kadācid’「ある時」といいながら年代を示すのは奇妙であり, 他は成立年 代であるのに，これだけが執筆の依頼された年代である.

それ故，この ‘dvādaśî' は年を示す数字とは考えられず，「第 12 日」の意味で, 恐らく dvādaśivirata ${ }^{10)}$ と関係を有すると思われる。 そのように理解すれば Kșem. が「断食していた (upoșita)」ことともよく符合し，全体は「ある時，第 12 日に断 食していた，趣味の良い彼（Kșem.）は，心の明るいバラモン，Rāmayaśasによっ て[執筆を] 依頼された」となる。これが正しければ， BKMの A. D. 1037 年成立 説の根拠は全く存在しない.

\section{Somapāda という人名}

Kșem. を Vișnu 信仰へと導いた師の名が, Sūryakānta 以降, 'Somapāda' とされ が, Bühler は 'Somācārya' とする ${ }^{11)}$ 。この人名は $B h M$ と BKMで言及される.

śrimadbhāgavatācāryasomapādābjarenubhih $\mid$

dhanyatāṃ yaḥ parāṃ prāpto nārāyaṇparāyaṇah $\| B h M$ (p. 850) ${ }^{12)}$

下線部において ‘pāda’を名前に含んでしまうと，後につづく '-abjareṇubhiḥ’ が理解困難になる。この偈は「バーガヴァ夕派の師 Soma の御足のいう蓮華の花 粉によって，最上の幸福を得た彼（Kșem.）は，ヴィシュヌ神に一身を捧げた.」 と読むべきで, Bühlerの方が正しかったことが明確である.

\section{3. 'Sajjanānanda' は人名ではない}

Sūryakānta は, 次に挙げる Som. の $A K$ の後書の一偈文に Rāmayaśas と Sajjanānanda という二人の人物が登場すると理解し, 後者を「最初に Kșem. に $A K$ の執 筆を要請した」人物として紹介する。

yasya rāmayaśāh sarvaprabandhaprerako dvijạ̣ |

prayātạ̣ sajjanānandah puṇyaprathamadūtatām ${ }^{13)} \| A K$ 後書 5 
これに関して Dattaray ${ }^{14)}$ が，この 'sajjanānanda’ は人名ではなく, a の Rāmayaśas にかかる修飾語であると訂正した。 Dattaray は特に言及しないが, この部分の Tib. 訳 ${ }^{15)}$ も彼の訂正を支持している。この偈には Rāmayaśas一人しか言及されて おらず, 全体は「彼 (Kșem. ) の全ての作品教唆者, バラモン, 善人の喜びである Rāmayaśas が, 彼にとって快い最初の使者となった.」と訳せる.

\section{Nakka=Somendra ?}

Som. は $A K$ の後書で, Kșem. に $A K$ の執筆を依頼した人物として, ある仏教 徒（saugata）の名を記している.

taṃ kadācit sukhāsīnaṃ suhṛd guṇavatāṃ varaḥ |

saugatạ khyātasukṛto nakkanāmā samabhyadhāt \|I $A K$ の後書 6

Sūryakānta はこの人物を「Kșem. の友人 (suhṛ)」とする。しかし，必然性はな い.「ある時，安楽に座っている彼（Kșem.）に，有徳者らの最上の友で, Nakka という，その善行がよく知られた仏教徒が話しかけた」とも読めよう。

筆者は，新たに Nakkaの名が言及されているらしい箇所を見い出した。それは， $A K$ の後書ではなく, やはり Som. の手になる $A K$ の第 108 章 Jīmūtavāhanāvadāna の冒頭で，彼が自身の別名に関して言及する箘所である.

somendranāmā tanayo 'tha tasya kavir niruddhāparanāmadheyah | asmin jinodārakathāprabandhe sampūrayișyaty avadānaśeșam \|| 4

この Das の校訂によれば, Som. は「'Niruddha' という別名を持つ詩人」か, または，「別名が隠されている詩人」であることになる。しかし，Tib，訳は mingźan nā ko（P: kā） źes brjod sñan dnags mkhan「別名が ‘Nāko’（北京版では 'Nākā’） という詩人」として，Skt. 原文と一致しない。チベットに伝わった $A K$ の Tib. 文 字音写のテクスト ${ }^{16)}$ では, この䇢所が Ka bi tstshannakkā pa rā nā ma dhe yah (kavicchan nakkāparanāmadheyah) となっている，Tib. 訳を参考にして，音写テクストから復元 を試みると, kaviś ca ${ }^{17)}$ nakkāparanāmadheyah というテクストが推定される. それ に基づいて全体を訳出すれば「そこで，詩人でもある，'Nakka'という別名を有 する, Som. という名の, 彼 (Kșem.) の息子が, この大部の勝者の物語の文学作 品において，残りのアヴァダーナを完成させるであろう.」となる.

'Nakka'が Som. の別名であるとすると，序文において Kṣem. に $A K$ 執筆を依 頼した Nakkaも実は Som.であり，Nakka は Ksem の友ではなく息子ではないか という推測がなされる。 
1) G. Bühler [1877]. Detailed Report of a tour in search of Sanskrit MSS. made in Kaśmi $r$, Rajputana and Central India. By G. Bühler. Extra number of the Journal of the Bombay Branch of the Royal Asiatic Society. Bombay. pp. 45-48.

2) Sūryakānta [1954]. Kșemendra Studies. Poona.

3) N. S. Shukla [1990]. Cultural trends in kashmir and Kșemendra. Delhi.

4) Uma Chakraborty [1991]. Kṣemendra. Delhi.

5) A. K. Warder [1992]. Indian Kāvya Literature. vol. VI. Delhi.

6）以下，Kșem. の著作については， $A K$ を除いて，Kāvyamālā 所収のものを用いた。 $A K$ については特に言及しない限り, Sarat Chandra Das の校訂を用いた.

7） Sarat Chandra Das の校訂本では Introductionとして冒頭に移されている.

8）但し，出版された校訂本では成立年代の記述は欠けており，1写本が年代を記す.Cf. Nitikalpataru, ed by V. P. Mahajan. Poona, 1956. Introduction, p. ii.

9）Kșem. は同時に著作成立時の王として Ananta 王（Laukika era 4104-4139=A. D. 1028-1063 在位) と Kalaśa 王（Laukika era 4139-4165=A. D. 1063-1089在位）に言及し ているので, 記されていない上二桁が確定でき, Laukika era で, SMが 4125 年（A. D. 1050)，AKが 4127 年（A. D. 1052），AVCが 4134 年（A. D. 1059）, DCが 4141 年（A.

D. 1066）に成立したことが分かる.

10) dvādaśīvrata については, P. V. Kane [1974]. History of Dharmaśāstra, Vol. V. pp. 95-.

11) Bühler [1877] p. 46.

12） $B K M$ (p. 620) のものもほど同文. 但し, cd が dhanyatāṃ yạ̣ parạ̣ yāto nārāyaṇaparāyaṇah.

13）Das の校訂では puṇyah prathamadūtatāṃ とある. Cf. J. W. de Jong [1979]. Text Remarks on the Bodhisattvāvadānakalpalatā. Tokyo. p. 300.

14) Rajatbaran Dattaray [1974]. A Critical Survey of the Life and Works of Ksemendra. Calcutta. pp. 104-107.

15) | gñis skyes dam pa'i skye bo dga' || rtsom pa thams cad skul byed pa| | dga' ba'i grags pa gan gi ni || bsod nams dan po’i pho ñar gyur |

16）デルゲ版, 及び, Das の校訂の底本となったものと同じ, ダライ・ラマ 5 世版 （Dharamsala で 1998 年に復刻されたもの）を参照した.

17） Tib. 訳に対応する語がないという問題は残るが，この偈の韻律は Upajāti であるか ら，第三音節に当たる-cchann は短でなければならないので, ca が推定される.

〈キーワード〉 Kṣemendra, Bṛhatkathāmañjarī, Avadānakalpalatā, Somendra, Nakka (東洋大学東洋学研究所研究員, 博士 (文学)) 